\title{
Forced expiratory indices in normal black Southern African children aged 6-19 years
}

\author{
M H Shamssain
}

\begin{abstract}
Forced vital capacity (FVC), forced expiratory volume in one second $\left(F E V_{1}\right)$, forced expiratory ratio $\left(\mathrm{FEV}_{1} / \mathrm{FVC} \times\right.$ 100), forced mid expiratory flow (FMF), and peak expiratory flow (PEF) were measured in 2000 non-smoking black African schoolchildren aged 6-19 years from Umtata in the Republic of Transkei in Southern Africa. FVC, FEV, FMF, and PEF were highly correlated with each other and all were highly correlated with age and standing height in both sexes. There was a significant negative correlation between $F E V_{1} / F V C$ and both age and standing height. An increase in the slope of the increase in FVC for both age and height occurred at 11 years and $143 \mathrm{~cm}$ in girls and at 13 years and 150 $\mathrm{cm}$ in boys. This continued for about two years and $10 \mathrm{~cm}$ in both groups before it declined. The mean values of $\mathrm{FEV}_{1}$, FEV $/$ FVC, and PEF in the present study were $14 \%$ lower than those obtained in black American schoolchildren. The present study is the largest study of urban black African schoolchildren and provides useful reference values.
\end{abstract}

Pulmonary function studies have been carried out in various populations to establish reference values and formulae from which normal values can be predicted according to age, sex, and standing height. These reference or normal values of respiratory function, which have been shown to depend on the ethnic and racial origin of the population, are used to identify abnormal values and hence the nature and degree of functional abnormality.

The aim of this study was to obtain reference values of pulmonary function for normal black schoolchildren from the Republic of Transkei in Southern Africa as these have not been reported previously. This is the largest study of pulmonary function in urban black schoolchildren to be reported.

\section{Methods}

Two thousand non-smoking, healthy black schoolchildren aged 6-19 years from various schools in Umtata, Republic of Transkei, were included in this study by the cluster sampling method. The Republic of Transkei is a small state in Southern Africa on the Indian Ocean with a population of 4.0 millions (latitude $31^{\circ} 19^{\prime} \mathrm{S}$, longitude $28^{\circ} 39^{\prime} \mathrm{E}$ ). All the children were black and from the Xhosa tribe (total population in Southern Africa 10 millions) and of the same socioeconomic status. A questionnaire from the British Medical Research Council was modified for this population. A local Xhosa speaking interviewer helped in filling in the questionnaires. All children with a history of respiratory disease were excluded from the study and 48 children were rejected because they were unable to perform spirometric tests adequately.

\section{MEASUREMENTS}

Forced expiratory indices were determined with an expired gas bellows spirometer (Vitalograph), with the subject standing and wearing a nose clip. The spirometer was calibrated with a 1 litre precision syringe (Vitalograph). The best of three attempts was selected. The best curve was that which produced the highest forced expiratory volume in one second $\left(\mathrm{FEV}_{1}\right)$, provided that the forced vital capacity (FVC) was close to the subject's best FVC. The following measurements were obtained from the spirometer: FVC, $\mathrm{FEV}_{1}$, forced expiratory ratio $\left(\mathrm{FEV}_{1} / \mathrm{FVC} \times 100\right)$, forced mid expiratory flow between $25 \%$ and $75 \%$ of FVC (FMF), and peak expiratory flow (PEF). All volumes were converted to body temperature and pressure saturated (BTPS)

The same equipment and observer were used for all subjects and the recordings were made between 8.00 and 13.00 hours over nine months. The mean (SD) ambient temperature was $18^{\circ}\left(2^{\circ}\right) \mathrm{C}$.

Age was calculated to the nearest six months from school records (table 1). Stand-
Department of Physiology, Faculty of Medicine and Health Sciences, University of Transkei, UNITRA, Private Bag XI, Umtata, Republic of Transkei, of Transkei, M H Shamssain

Reprint requests to: Dr Shamssain

Accepted 14 November 1990

Table 1 Age distribution of the children in the study

\begin{tabular}{lllllllllllllll}
\hline Age $(y):$ & 6 & 7 & 8 & 9 & 10 & 11 & 12 & 13 & 14 & 15 & 16 & 17 & 18 & 19 \\
\hline Boys (n) & 64 & 64 & 61 & 61 & 74 & 66 & 73 & 75 & 60 & 71, & 75 & 70 & 83 & 76 \\
Girls (n) & 57 & 72 & 67 & 66 & 67 & 75 & 80 & 72 & 65 & 75 & 84 & 76 & 86 & 84 \\
\hline
\end{tabular}


Table 2 Multiple regression coefficients in equations using height and age as explanatory variables (standard errors in parentheses)

\begin{tabular}{|c|c|c|c|c|c|}
\hline \multirow[b]{2}{*}{ Dependent variables } & \multirow[b]{2}{*}{ Sex } & \multirow[b]{2}{*}{ Constant } & \multicolumn{3}{|c|}{ Independent variables } \\
\hline & & & Height $(\mathrm{cm})$ & Age (y) & $R^{2}$ \\
\hline \multirow[t]{2}{*}{ FVC (1) } & $\mathbf{M}$ & $\begin{array}{c}-3 \cdot 744^{\star \star \star} \\
(0 \cdot 264)\end{array}$ & $\begin{array}{l}0.031^{\star \star \star} \\
(0.003)\end{array}$ & $\begin{array}{l}0.138 \star \star \star \star \\
(0.013)\end{array}$ & $0 \cdot 764$ \\
\hline & $\mathbf{F}$ & $\begin{array}{c}-2 \cdot 855^{\star \star \star} \\
(0.223)\end{array}$ & $\begin{array}{l}0.026^{\star \star \star \star} \\
(0.002)\end{array}$ & $\begin{array}{l}0.110^{\star \star \star} \\
(0.009)\end{array}$ & $0 \cdot 723$ \\
\hline \multirow[t]{2}{*}{$\mathrm{FEV}_{1}(\mathbf{1})$} & $\mathbf{M}$ & $\begin{array}{c}-2 \cdot 705^{\star \star \star} \\
(0.214)\end{array}$ & $\begin{array}{l}0.023^{\star \star \star \star} \\
(0.002)\end{array}$ & $\begin{array}{l}0.107^{\star \star \star} \\
(0.011)\end{array}$ & 0.742 \\
\hline & $\mathbf{F}$ & $\begin{array}{c}-1 \cdot 807^{\star \star \star \star} \\
(0 \cdot 183)\end{array}$ & $\begin{array}{l}0.018^{\star \star \star} \\
(0.002)\end{array}$ & $\begin{array}{l}0.088^{\star \star \star} \\
(0.008)\end{array}$ & 0.681 \\
\hline \multirow[t]{2}{*}{$\mathrm{FEV}_{1} \%$} & $\mathbf{M}$ & $\begin{array}{l}101 \cdot 246^{\star \star \star} \\
(4 \cdot 323)\end{array}$ & $\begin{array}{c}-0 \cdot 104^{\star \star} \\
(0.044)\end{array}$ & $\begin{array}{r}-0.352^{\star} \\
(0.213)\end{array}$ & 0.097 \\
\hline & $\mathbf{F}$ & $\begin{array}{l}108 \cdot 794^{\star \star \star} \\
(4 \cdot 652)\end{array}$ & $\begin{array}{c}-0.152^{\star \star \star} \\
(0.045)\end{array}$ & $\begin{array}{r}-0.391^{\star} \\
(0.196)\end{array}$ & $0 \cdot 119$ \\
\hline \multirow[t]{2}{*}{ FMF $(1 / s)$} & $\mathbf{M}$ & $\begin{array}{c}-1.795^{\star \star \star} \\
(0.534)\end{array}$ & $\begin{array}{c}-0.009 \\
(0.005)\end{array}$ & $\begin{array}{l}0 \cdot 219 \star \star \star \\
(0.026)\end{array}$ & 0.405 \\
\hline & $\mathbf{F}$ & $\begin{array}{l}0.083 \\
(0.431)\end{array}$ & $\begin{array}{c}-0.002 \\
(0.004)\end{array}$ & $\begin{array}{l}0 \cdot 188^{\star \star \star} \\
(0 \cdot 018)\end{array}$ & 0.334 \\
\hline \multirow[t]{2}{*}{$\operatorname{PEF}(1 / s)$} & $\mathbf{M}$ & $\begin{array}{c}-4 \cdot 195^{\star \star \star} \\
(0 \cdot 714)\end{array}$ & $\begin{array}{l}0.036^{\star \star \star} \\
(0.007)\end{array}$ & $\begin{array}{l}0.262^{\star \star \star} \\
(0.035)\end{array}$ & 0.504 \\
\hline & $\mathbf{F}$ & $\begin{array}{c}-0.868 \\
(0.612)\end{array}$ & $\begin{array}{l}0.006 \\
(0.005)\end{array}$ & $\begin{array}{l}0.295^{\star \star \star} \\
(0.026)\end{array}$ & 0.437 \\
\hline
\end{tabular}

${ }^{\star} \mathrm{p}<0.05 ; \star \star \mathrm{p}<0.01 ; \star \star \star \mathrm{p}<0.001$

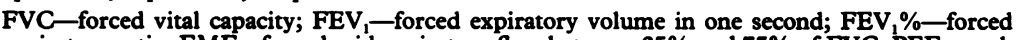
expiratory ratio; FMF-forced mid expiratory flow between $25 \%$ and $75 \%$ of FVC; PEF-peak expiratory flow; $\mathbf{R}^{2}$-proportion of the variability in the data explained by the fitted model.

ing height was measured to $0 \cdot 1 \mathrm{~cm}$ with a portable stadiometer and body weight to $0.1 \mathrm{~kg}$ with portable field survey scales according to the recommendations of the International Biological Programme. ${ }^{1}$

\section{DATA ANALYSIS}

The data were initially plotted graphically on box plots and scatter plots with percentile curves estimated by linear regression. Correlation coefficients were calculated for the various physical and lung function measurements. Multiple regression analysis was used to assess the simultaneous effects of age, height, weight, and sex on lung function measures. Calculations were performed with the Statgraphic computer program. ${ }^{2}$

\section{Results}

The age distribution of the children is shown in table 1 and the multiple regression coefficients for the equations using height and age as explanatory variables in table 2 . This allows prediction of pulmonary function according to height, age, and sex. For example, predicted FVC in boys =

$$
-3.744+0.031 \text { (HEIGHT) }+0.138 \text { (AGE). }
$$

FVC, FEV, FMF, and PEF were highly correlated with each other and all were highly correlated with age and standing height in both sexes. FVC and FEV 1 values for boys and girls of different heights are given in table 3 . There was a significant negative correlation between
$\mathrm{FEV}_{1} / \mathrm{FVC}$ and both age and height. After age and height have been allowed for, a difference in lung function indices between boys and girls was still evident. The effect of weight was not significant. *

\section{Discussion}

Previous studies of black children have included 521 girls and 501 boys from the United States (Schoenberg et al ${ }^{3}$ ), 1041 black children, also from the United States, (Dockery et $a l^{4}$ ), 161 boys and 144 girls from Africa (Miller et $a l^{5}$ ), and 97 children from Upper Volta (Huizinga and Glanville ${ }^{6}$ ). Thus our report presents the largest study of urban black schoolchildren.

Although body weight correlates significantly with lung function measurements, body weight and age are strongly related and when standing height, age, and body weight were included in the regression analysis the coefficient for body weight was not significant.

Lung function values increased progressively with increasing age in boys and girls. Being dependent on body size, they levelled off in girls at the age of 17 years and in boys at the age of 18 years. Among girls there was an increase in the slope of the FVC/age line at 11 years, which continued for two years. A similar increase was seen in the slope of the FVC/ height line, starting at $143 \mathrm{~cm}$ and continuing for $10 \mathrm{~cm}$. FVC continued to increase up to 17 years. Among boys this acceleration started at 13 years and at $150 \mathrm{~cm}$ and continued for similar periods. FVC continued to increase up to 18 years. These findings are related to the growth spurt seen in this population ${ }^{7}$ : the adolescent growth spurt starts in girls at around 11 years but in boys at around 13 years. The mean duration of the pubertal period in our study was two years for both boys and girls. ${ }^{7}$ After the age of 6 years the peak height velocity was $7.7 \mathrm{~cm} / \mathrm{y}$ in boys and $7.9 \mathrm{~cm} / \mathrm{y}$ in girls.

Carson et $\mathrm{l}^{8}$ found an increase in the slope of the PEF/age line at 12 years among Irish girls and this continued for two years. A similar increase was seen in the slope of the PEF/ height line, starting at $145 \mathrm{~cm}$ and continuing for $15 \mathrm{~cm}$. Among Irish boys this change started at 14 years and at $155 \mathrm{~cm}$ and continued for similar periods. An acceleration of lung function growth in relation to height with the onset of puberty was seen in the study by Dickman and associates. ${ }^{9}$ They suggested that this change occurred at a height of about $152 \cdot 4 \mathrm{~cm}$

Dockery $e t \mathrm{al}^{4}$ found that black children in

$\star$ Further data may be obtained from the author.

Table 3 Mean values forced vital capacity (FVC) and forced expiratory volume in one second (FEV $V_{1}$ in boys and girls

\begin{tabular}{|c|c|c|c|c|c|c|c|c|c|c|c|c|c|c|c|}
\hline Height $(\mathrm{cm})$ : & & 120 & 122 & 124 & 126 & 128 & 130 & 132 & 134 & 136 & 138 & 140 & 142 & 144 & 146 \\
\hline $\begin{array}{l}\text { FVC (1) } \\
\mathrm{FEV}_{1}(1)\end{array}$ & $\begin{array}{r}\mathbf{M} \\
\mathbf{F} \\
\mathbf{M} \\
\mathbf{F}\end{array}$ & $\begin{array}{l}1.19 \\
1.17 \\
1.02 \\
1.00\end{array}$ & $\begin{array}{l}1 \cdot 21 \\
1 \cdot 20 \\
1 \cdot 16 \\
1 \cdot 10\end{array}$ & $\begin{array}{l}1 \cdot 28 \\
1 \cdot 24 \\
1 \cdot 20 \\
1 \cdot 18\end{array}$ & $\begin{array}{l}1 \cdot 37 \\
1 \cdot 29 \\
1 \cdot 25 \\
1 \cdot 15\end{array}$ & $\begin{array}{l}1.43 \\
1.35 \\
1.31 \\
1.28\end{array}$ & $\begin{array}{l}1.50 \\
1.45 \\
1.36 \\
1.30\end{array}$ & $\begin{array}{l}1.65 \\
1.53 \\
1.58 \\
1.40\end{array}$ & $\begin{array}{l}1.72 \\
1.69 \\
1.60 \\
1.48\end{array}$ & $\begin{array}{l}1.80 \\
1.75 \\
1.66 \\
1.51\end{array}$ & $\begin{array}{l}1.86 \\
1.80 \\
1.69 \\
1.58\end{array}$ & $\begin{array}{l}2.00 \\
1.82 \\
1.79 \\
1.63\end{array}$ & $\begin{array}{l}2.07 \\
2.00 \\
1.81 \\
1.77\end{array}$ & $\begin{array}{l}2.09 \\
2.05 \\
1.90 \\
1.85\end{array}$ & $\begin{array}{l}2.30 \\
2.25 \\
1.93 \\
1.90\end{array}$ \\
\hline
\end{tabular}


Figure 1 Percentile curves of forced vital capacity $(F V C)$ plotted against standing height in boys $(F V C=0.022 \mathrm{Ht}$ $-2.469, r=0.808, S E E$ $=0.00061)$. The inner lines indicate the standard error of the mean of FVC.

Figure 2 Percentile curves of forced vital capacity (FVC) plotted against standing height in girls $(F V C=0.024 \mathrm{Ht}$ $-2.747, r=0.796, S E E$ $=0.00061$. The inner lines indicate the standard error of the mean of FVC.
FVC (1)

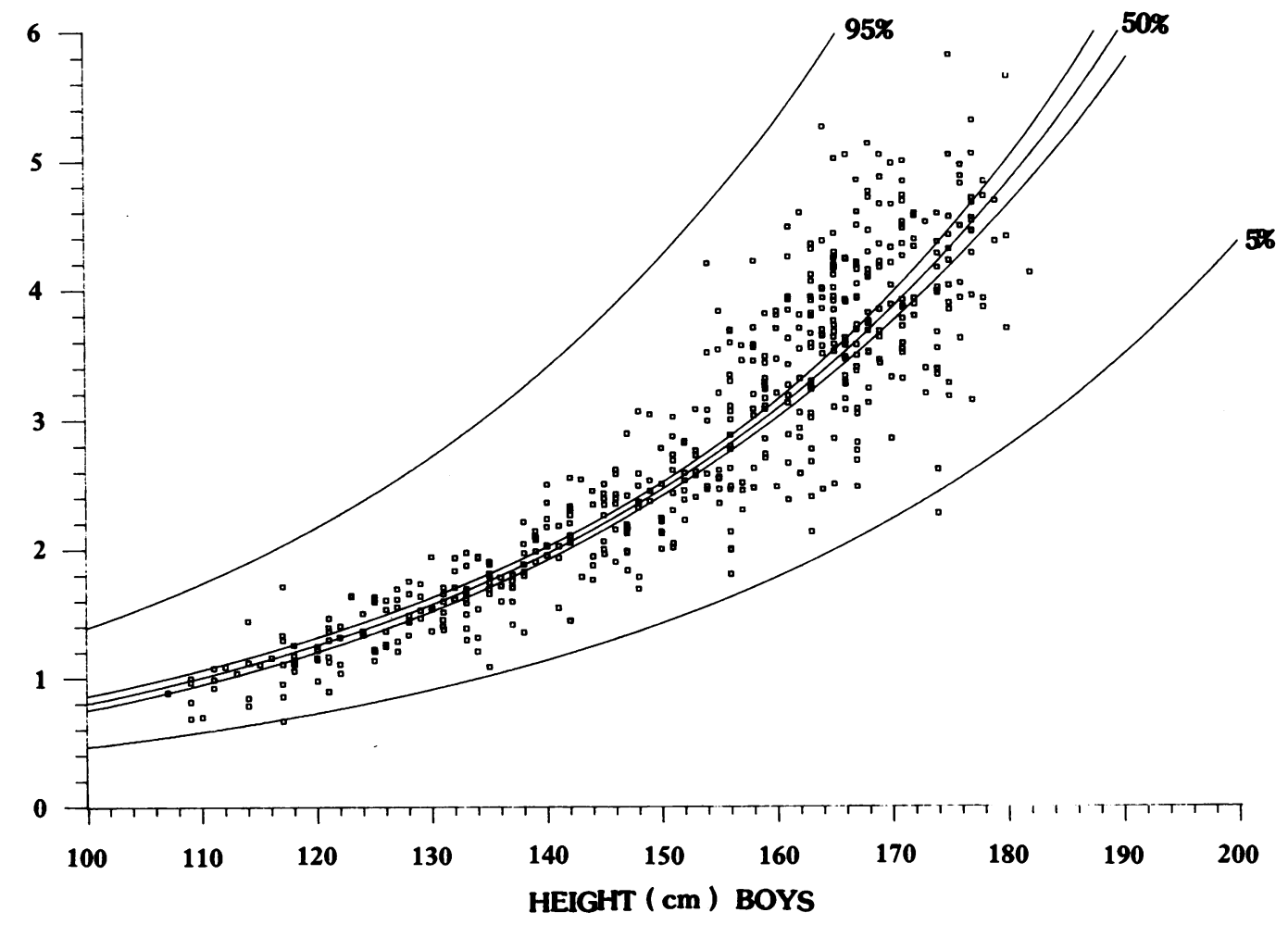

FVC (1)

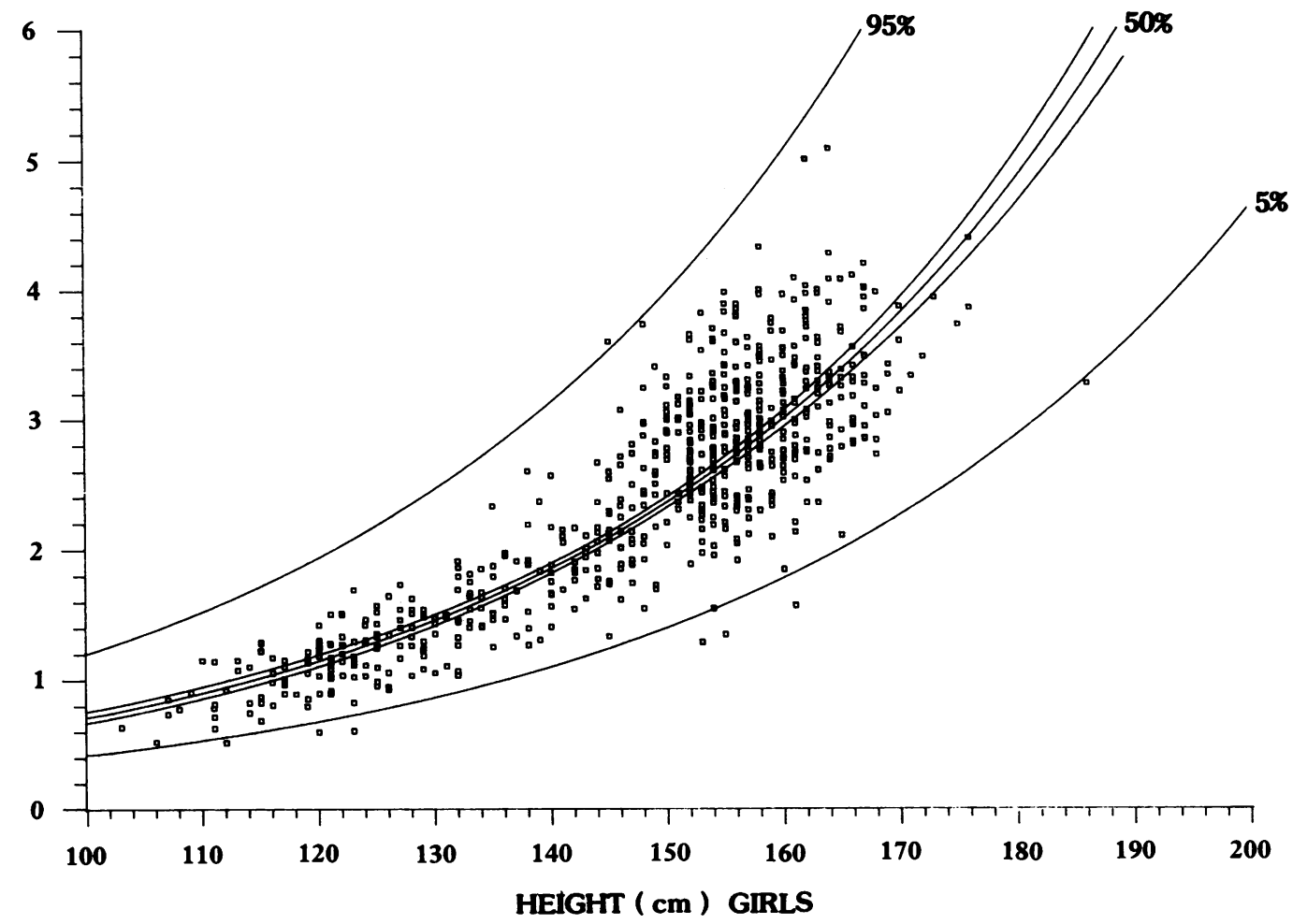

\begin{tabular}{|c|c|c|c|c|c|c|c|c|c|c|c|c|c|c|c|}
\hline 148 & 150 & 152 & 154 & 156 & 158 & 160 & 162 & 164 & 166 & 168 & 170 & 172 & 174 & 176 & 178 \\
\hline $\begin{array}{l}2.38 \\
2.33 \\
2.00 \\
1.97\end{array}$ & $\begin{array}{l}2.44 \\
2.38 \\
2.05 \\
2.00\end{array}$ & $\begin{array}{l}2 \cdot 52 \\
2 \cdot 48 \\
2 \cdot 14 \\
2 \cdot 10\end{array}$ & $\begin{array}{l}2.91 \\
2.83 \\
2.32 \\
2 \cdot 23\end{array}$ & $\begin{array}{l}3.02 \\
2.93 \\
2 \cdot 39 \\
2 \cdot 30\end{array}$ & $\begin{array}{l}3 \cdot 17 \\
3 \cdot 10 \\
2 \cdot 51 \\
2 \cdot 35\end{array}$ & $\begin{array}{l}3 \cdot 40 \\
3 \cdot 15 \\
2 \cdot 73 \\
2 \cdot 40\end{array}$ & $\begin{array}{l}3.49 \\
3 \cdot 16 \\
2.84 \\
2 \cdot 42\end{array}$ & $\begin{array}{l}3.75 \\
3 \cdot 34 \\
3.04 \\
2 \cdot 48\end{array}$ & $\begin{array}{l}3 \cdot 86 \\
3 \cdot 36 \\
2 \cdot 89 \\
2 \cdot 58\end{array}$ & $\begin{array}{l}3.89 \\
3.43 \\
2.95 \\
2.64\end{array}$ & $\begin{array}{l}3.91 \\
2.97\end{array}$ & 3.28 & $\begin{array}{l}4 \cdot 27 \\
3 \cdot 19\end{array}$ & $\begin{array}{l}4 \cdot 32 \\
3 \cdot 40\end{array}$ & 3.41 \\
\hline
\end{tabular}


Figure 3 Percentile curves of forced expiratory volume in one second ( FEV ${ }_{1}$ ) plotted against standing height in boys $\left(F E V_{1}=0.021 \mathrm{Ht}\right.$ $2 \cdot 524, r=0 \cdot 884, S E E=$ $0.00042)$. The inner lines indicate the standard error of the mean of FEV

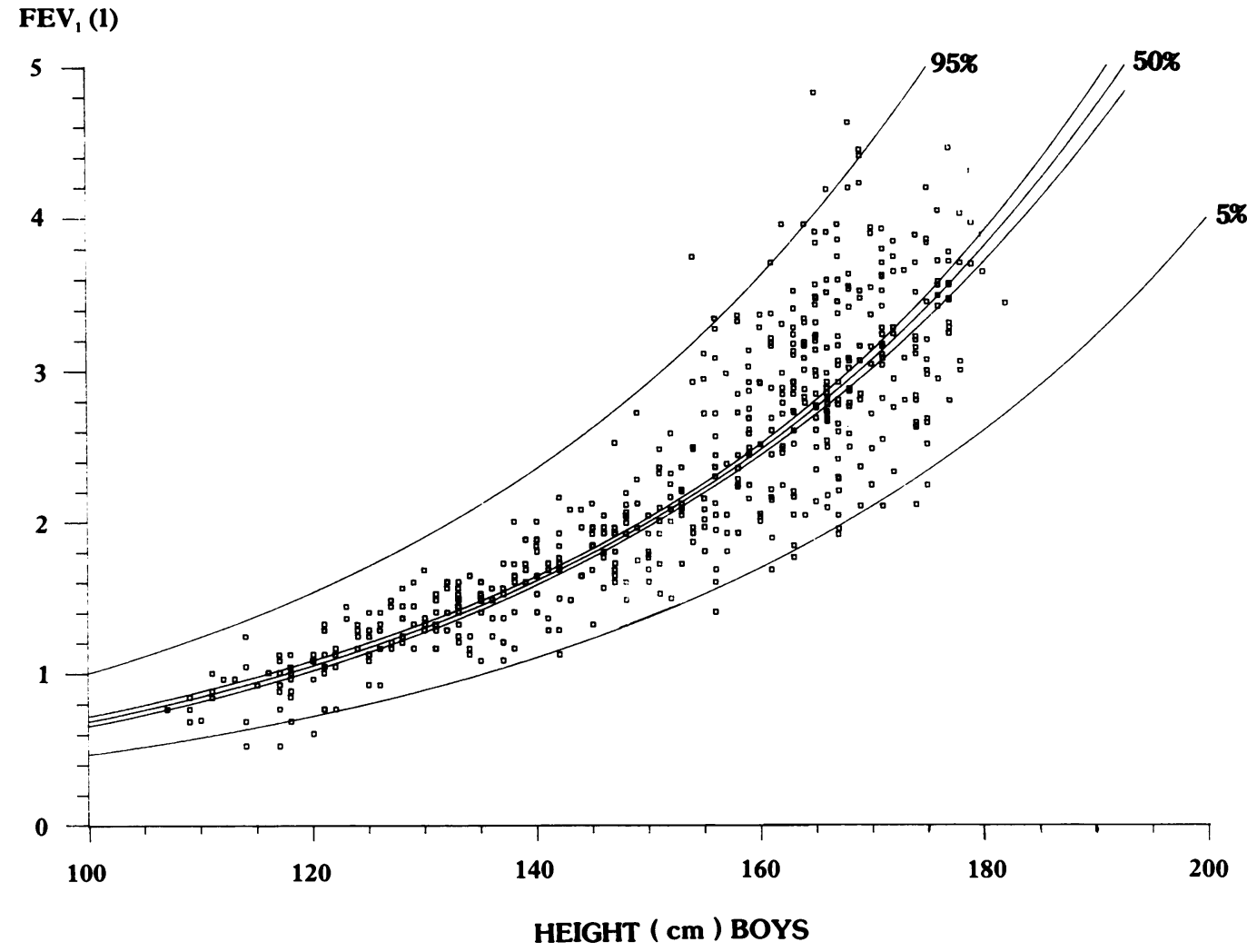

$\operatorname{FEV}_{1}(1)$

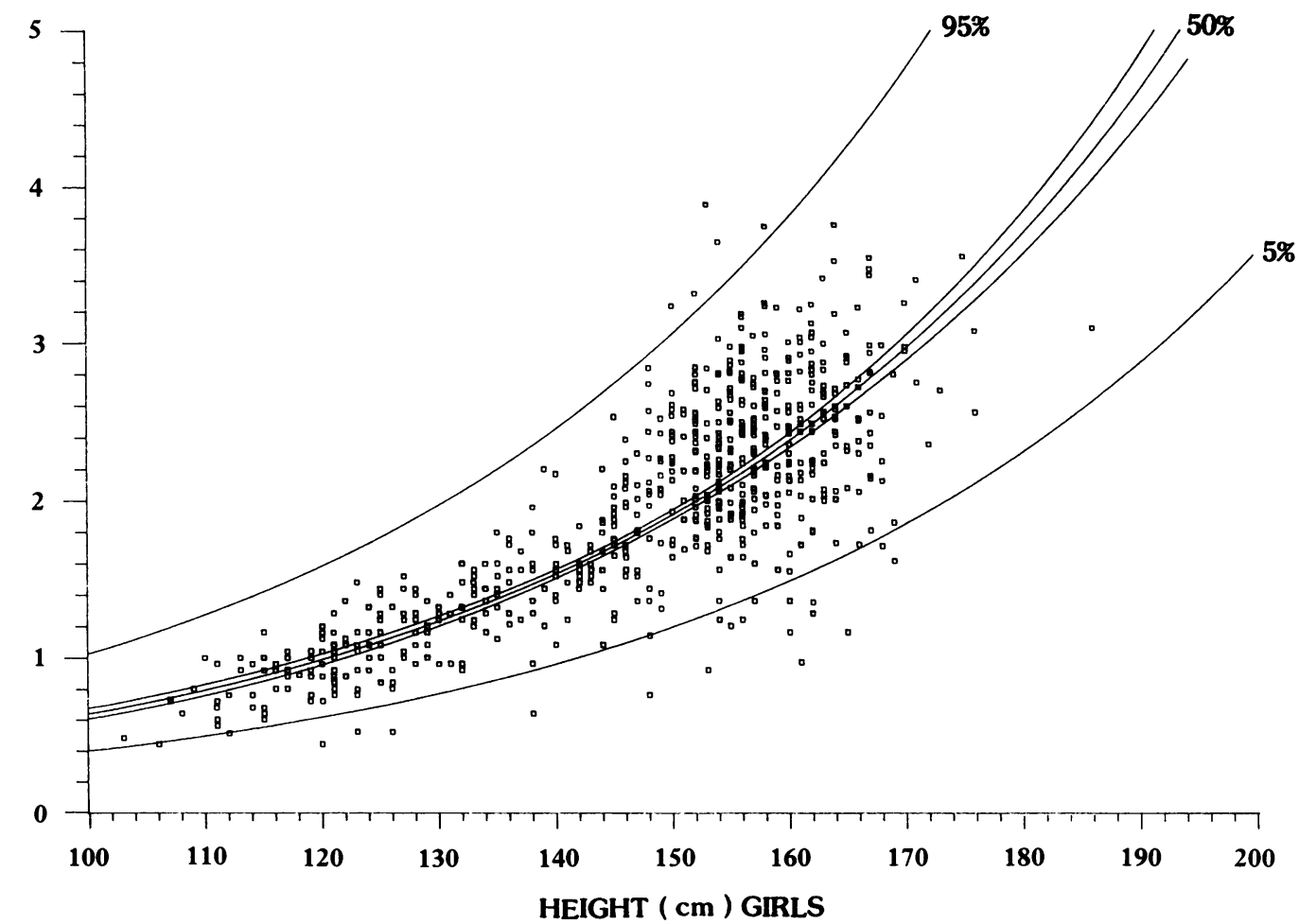

the United States had median values of FVC and $\mathrm{FEV}_{1}$ that were about $13 \%$ lower than those for white children of the same sex and standing height. There was no difference between black and white children in the $\mathrm{FEV}_{1}$ / FVC ratio for a given level of FVC.
A centile chart is the best method of presenting normal values for height and weight, and the same method may reasonably be used for lung function data. Percentile charts of FVC and $\mathrm{FEV}_{1}$ plotted against height can be applied easily by respiratory physicians to assess the 
lung function of children. Our lung function growth charts have the advantage of being derived from a large data base, uniformly collected with exactly the same equipment and criteria for inclusion. The plotted curves can be used directly, or the regression equations can be used to obtain predicted values. There were few boys over $180 \mathrm{~cm}$ in height and few girls over $170 \mathrm{~cm}$, and there were few of either sex less than $110 \mathrm{~cm}$; so the percentile graphs in these ranges (figs 1-4) cannot be regarded as reliable.

The lung function values for the children in this study were compared with those for black children elsewhere. The rate of increase in FVC with standing height in adolescent black African boys and girls was similar to that seen in adolescent Libyan boys and girls (90 and $45 \mathrm{ml} / \mathrm{cm}$ ) in our previous study. ${ }^{10}$ The FVC values for the two populations were similar for the same height and sex. Mean values of $\mathrm{FEV}_{1}$, $\mathrm{FEV}_{1} / \mathrm{FVC}$, and PEF were, however, around $14 \%$ higher in black American children studied by Schoenberg et $a l^{3}$ than in black African children in our study for the same height and sex. Black American children were also taller than the black Africans. Black African children in the present study had lower FVC, $\mathrm{FEV}_{1}$, and PEF values (around 12.8\% lower) and were shorter than African children studied by Miller et $a l^{5}$ for the same age and sex, and they were also lower than the values seen in Afrocaribbean children living in Nottingham. ${ }^{11}$ Predicted values of FVC, $\mathrm{FEV}_{1}$, and $\mathrm{FEV}_{1} / \mathrm{FVC}$ in the present study were, however, higher than the predicted values in children from Upper Volta studied by Huizinga and Glanville. ${ }^{6}$ The PEF values obtained in the present study were lower than those seen in Ethiopian children studied by Teklu et al, ${ }^{12}$ whereas FVC and $\mathrm{FEV}_{1}$ were higher than those obtained in Ethiopian schoolchildren at Adi-Arkai (altitude $1500 \mathrm{~m})^{13}$ and similar to the values obtained in schoolchildren at Debarech on the edge of the Simien plateau (altitude $3000 \mathrm{~m}$ ). These differences in pulmonary function might be due to the way the measurements were made or to altitude.

The present results show that forced expiratory indices in black people in Africa are lower than in black people in the United States. The present results reflect lung function among healthy urban black African schoolchildren living in the Republic of Transkei and can be used as reference values for urban black Southern African schoolchildren.

I thank the University of Transkei for approving and funding the present study; Professor D N Jafta (Professor of African languages, University of Transkei) for translating the respiratory questionnaire from English to Xhosa); the principals of various schools in Umtata for arranging the visits; and Mrs K P Klaas for her technical help.

1 Weiner JB, Lourie JA. Human biology: a guide to field methods. Oxford: Blackwell, 1969:76-8.

2 Statistical Graphic Corporation. "Statgraphic" statistical graphic system: (1986-STSC.) 2115 East Jefferson Street, Rockville, Maryland 20852,1986.

3 Schoenberg JB, Beck GJ, Bouhuys A. Growth and decay of pulmonary function in healthy blacks and whites. Respir Physiol 1978;33:367-93.

4 Dockery DW, Berkey CS, Ware JH, Speizer FE, Ferris BG Distribution of forced vital capacity and forced expiratory volume in one second in children 6-11 years of age. Am Rev Respir Dis 1983;128:405-12.

5 Miller GJ, Saunders MJ, Gilson RJC, Ashcroft MT. Lung function of healthy boys and girls in Jamaica in relation to ethnic composition, test exercise performance, and habitual physical activity. Thorax 1977;32:486-96.

6 Huizinga J, Glanville EV. Vital capacity and timed vital capacity in the Kurumba from Upper Volta. South African Journal of Science 1968; February.

7 Shamssain MH. Growth of normal black southern African children aged 6-19 years. J Trop Pediatr (in press).

8 Carson JWK, Hoey H, Taylor MRH. Growth and other factors affecting peak expiratory flow rate. Arch Dis Child 1989;64:96-102.

9 Dickman ML, Schmidt CD, Gardner RM. Spirometric standards for normal children and adolescents (age 5 years through 18 years). Am Rev Respir Dis 1971;104:680-7.

10 Shamssain MH, Thompson, J, Ogston SA. Forced expiratory indices in normal Libyan children aged 6-19 years. Thorax 1988;43:467-70.

11 Patrick JM, Patel A. Ethnic differences in the growth of lung function in children: a cross-sectional study in inner-city Nottingham. Ann Hum Biol 1986;13:307-15.

12 Teklu B, Seboxa T, Mills RJ. Peak expiratory flow in normal Ethiopian children and adults in Addis Ababa. Br J Dis Chest 1987;81:176-81.

13 Harrison GA, Kuchemann, Moore MAS, et al. The effects of altitudinal variation in Ethiopian populations. Philos Trans $R$ Soc Lond (Biol) 1969;256:147-82. 